\title{
Electroadsorption of arsenic from natural water in granular activated carbon
}

\author{
Jean-Mackson Beralus ${ }^{1}$, Ramiro Ruiz-Rosas ${ }^{2}$, Diego Cazorla-Amorós ${ }^{2}$ and Emilia Morallón ${ }^{1}$ * \\ ' Departamento de Química-Física e Instituto Universitario de Materiales, University of Alicante, San Vicente del Raspeig, Spain \\ ${ }^{2}$ Departamento de Química Inorgánica e Instituto Universitario de Materiales, University of Alicante, San Vicente del Raspeig, Spain
}

\section{Edited by:}

Ashok K. Sundramoorthy, University

of Wisconsin-Madison, USA

\section{Reviewed by:}

Yi-Cheng Wang, University of

Wisconsin-Madison, USA

Nael G. Yasri, University of Wisconsin,

USA

\section{*Correspondence:}

Emilia Morallón, Departamento de

Química Física e Instituto

Universitario de Materiales, University

of Alicante, P.O. Box 99, San Vicente

del Raspeig E-03080, Spain

e-mail:morallon@ua.es
The adsorption and electroadsorption of arsenic from a natural water has been studied in a filter-press electrochemical cell using a commercial granular activated carbon as adsorbent and $\mathrm{Pt} / \mathrm{Ti}$ and graphite as electrodes. A significant reduction of the arsenic concentration is achieved when current is imposed between the electrodes, especially when the activated carbon was located in the vicinity of the anode. This enhancement can be explained in terms of the presence of electrostatic interactions between the polarized carbon surface and the arsenic ions, and changes in the distribution of most stable species of arsenic in solution due to As(III) to As(V) oxidation. In summary, electrochemical adsorption on a filterpress cell can be used for enhancement the arsenic remediation with activated carbon in the treatment of a real groundwater.

Keywords: electroadsorption, water treatment, heavy metals remediation, activated carbon

\section{INTRODUCTION}

Thanks to the combination of high surface area, chemical and physical stability, adjustable surface chemistry, and reduced production costs, activated carbon is the preferred adsorbent for the removal of organic and inorganic pollutants from polluted waters. The availability of different techniques for tuning their surface chemistry and their pore size distribution makes possible to adapt their surface characteristics in order to match the requirements to enhance as much as possible the adsorption of a given component from a water or gas mixture. Adsorption treatments using these kind of porous carbon materials are known to combine a high degree of efficiency with a reasonable cost (Derbyshire et al., 2001; Radovic et al., 2001). More particularly, remediation of metallic ions in concentrations in the range of parts per million (ppm) using activated carbon as adsorbent has been proved to be accomplishable (Corapcioglu and Huang, 1987a; Bailey et al., 1999; Babel and Kurniawan, 2003; Kobya et al., 2005). But, it is much more difficult to find examples about the treatment of water polluted with heavy metals in concentrations under the milligram per liter. In these conditions, activated carbons are reported to be an ineffective adsorbent for water treatment (Pattanayak et al., 2000; Babić et al., 2002). In those cases, the application of a controlled electric potential to the adsorbent can enhance adsorption by enabling the formation of an electric double layer, which can be partially formed by heavy metal ions, on the surface of the activated carbon in a process known as electroadsorption (Ban et al., 1998). This phenomenon shares the same fundamentals as the energy storage in supercapacitors (Ghosh and Lee, 2012) and the capacitive deionization for water purification (Gabelich et al., 2002; Noked et al., 2009), and it is only possible in materials with adequate pore size distribution and acceptable conductivity, such as activated carbons.
Arsenic (As) is a water pollutant that can be mainly found in rocks in the form of FeAsS, $\mathrm{As}_{2} \mathrm{~S}_{2}$, and $\mathrm{As}_{2} \mathrm{~S}_{3}$. It is usually present in natural waters at concentration of less than $1-2 \mu \mathrm{g} / \mathrm{L}$. However, it is possible to find groundwater reservoirs that are in contact with sulfide mineral deposits and sedimentary deposits from volcanic rocks and consequently show higher concentrations (Mohan and Pittman, 2007; Tyson, 2013). Arsenic is well known by its high toxicity, and even if it is usually found in low amounts in surface and ground waters, the health risks associated to arsenic exposure cannot be ignored, which is reflected by the worldwide trend for strong regulation on its allowable limit (Mohan and Pittman, 2007; Tyson, 2013; Nasser and Kheir-Bek, 2014). The World Health Organization considers arsenic pollution of groundwater a threat for human health in south Asia (WHO, "Guidelines for drinkingwater quality”, chapter 12, fourth edition 2011. Accessed October 3, 2014, http://www.who.int/water_sanitation_health/publications/ 2011/dwq_chapters/en/). Moreover, the inherent difficulties for arsenic quantification and speciation at low concentration levels, because of the number of the possible species that can exist in water depending on arsenic oxidation state and $\mathrm{pH}$ of water, makes even more challenging the development of remediation techniques (Tyson, 2013). Removal of arsenic from water is usually achieved by coagulation (Lee et al., 2003; Gomes et al., 2007), precipitation (Borho and Wilderer, 1996), membrane separation (An et al., 2005), and adsorption (Mohan and Pittman, 2007; Giles et al., 2011). On the other hand, electrochemical methods have been used for identification, quantification, and also removal of arsenic in very low concentrations (Mohan and Pittman, 2007; Morallón et al., 2009; Bain et al., 2010), although those studies were carried out in synthetic waters.

The removal of $\mathrm{As}(\mathrm{III})$ and $\mathrm{As}(\mathrm{V})$ species in water can be attained using adsorption on porous carbon materials under 
restricted conditions, which have been already reported in the past (Eguez and Cho, 1987; Rajakovic, 1992; Lorenzen et al., 1995). For instance, Eguez and Cho reported that uptake of As(III) over an activated carbon was found to be almost constant at $\mathrm{pH}$ ranging between 0.16 and 3.5. However, the activated carbon showed a maximum $\mathrm{As}(\mathrm{V})$ adsorption at $\mathrm{pH} 2.3$ on a $\mathrm{pH}$ interval between 0.86 and 6.33 (Eguez and Cho, 1987). In a different study, three activated carbons with different ash contents were tested for As removal, and the best results were found in the case of the porous carbon with the higher ash content (Lorenzen et al., 1995). Similar results using porous carbon materials as adsorbents whilst modifying their surface chemistry by the addition of metals or surface groups have been reported during the last 20 years (Pattanayak et al., 2000; Babić et al., 2002; Navarro and Alguacil, 2002; Gu et al., 2005; Chen et al., 2007). Nevertheless, the allowable concentration of arsenic in drinkable water was lowered from 50 to $10 \mu \mathrm{g} / \mathrm{L}$ in USA and the European Union several years ago (Mohan and Pittman, 2007), and as a consequence, a huge interest for the development of new and effective As remediation techniques have risen in the last years, for what the use of carbon materials as adsorbents can be a possible answer. Granular activated carbon (GAC) and activated carbon fibers (ACF) are probably the most adequate materials for such purpose, given their economic and technical advantages in terms of handling, safety regulations, and availability, between others. This is reflected by the amount of recent literature reporting their use for such purpose (Zhang et al., 2010b; Giles et al., 2011; Sun et al., 2013). More advanced carbon materials, such as carbon nanotubes and graphene oxide, have also been proposed in hybrid materials for the removal of As in water solution (Zhang et al., 2010a; Chen et al., 2013), however, they are far from being ready to be implemented for water treatment, specially due to their production cost.

There exist only a few works regarding electroadsorption of arsenic on porous carbon materials, although they show rather promising results that demonstrate the feasibility of such technique for this challenging task (Morallón et al., 2009; Bain et al., 2010). Focused on this specific topic, the work by Bain et al. reports the results of adsorption, electroadsorption, and electrodesorption of As alone and also in the presence of $\mathrm{Ni}, \mathrm{Fe}$, and $\mathrm{Cr}$ over a GAC (Bain et al., 2010). They carried out the electroadsorption in a batch cell using Pt-based electrodes and anodic potentials ranging from 1.0 to $1.5 \mathrm{~V}$, obtaining an outstanding removal of more than $80 \%$ in a solution containing $85.7 \mu \mathrm{g} / \mathrm{L}$ of As after imposing an anodic potential of $1.5 \mathrm{~V}$ for $24 \mathrm{~h}$.

Our research group has previously studied the adsorption and speciation of As in the ppm range over platinum and carbon black electrodes using a three electrode cell (Morallón et al., 2009), paying special attention to the mechanisms of interaction of As with the carbon surface and the electrochemical reactions. However, the present work focuses in the feasibility of using As electroadsorption on activated carbon from an applied point of view. With this objective in mind, removal of arsenic in parts per billion (ppb) concentration from a polluted natural water pumped from a Spanish well has been studied for the first time in a filter-press cell using as adsorbent an activated carbon commercialized for wastewater treatment. When envisaging the viability of a technology in economical and engineering aspects, it is important to consider the use of materials and equipment that have been proved to be implementable and scalable to larger sizes. This is in line with the use of the selected activated carbon and the filter-press cell for the electroadsorption treatment, which is a readily available and widely implemented device in the water treatment industry. For stablishing the role of the polarization on the electroadsorption process, the effect of emplacing the activated carbon in the anodic or in the cathodic compartment has been studied. Kinetic studies have been carried out in order to elucidate the effect on diffusivity and adsorbed amount as well as the best polarization condition for As removal. The results in this work show that by using electroadsorption on GAC in a filter-press cell, it is possible to increase the As adsorption capacity of the porous carbon in about $50 \%$ compared to the adsorption process.

\section{MATERIALS AND METHODS CHARACTERIZATION OF GRANULAR ACTIVATED CARBON}

The adsorbent used for this study was a commercial GAC provided by Waterlink Suctliffe Carbons. Its porous structure was characterized by $\mathrm{N}_{2}$ adsorption-desorption at $-196^{\circ} \mathrm{C}$ and $\mathrm{CO}_{2}$ adsorption at $0^{\circ} \mathrm{C}$ that were performed in an Autosorb-6 equipment (Quantachrome). The sample was previously outgassed at $250^{\circ} \mathrm{C}$ under vacuum during at least $4 \mathrm{~h}$ to ensure complete removal of moisture and adsorbed gases. The apparent surface area $\left(\mathrm{S}_{\mathrm{BET}}\right)$ was determined from the $\mathrm{N}_{2}$ adsorption isotherm by applying the BET equation at relative pressures between 0.05 and 0.20 . The total micropore volume $\left(V_{\mathrm{DR}}^{\mathrm{N} 2}\right)$ was determined using Dubinin Radushkevich (DR) equation on the nitrogen adsorption isotherm in the interval of relative pressures between 0.005 and 0.10 . Similarly, the narrow micropore volume $\left(V_{\mathrm{DR}}^{\mathrm{CO}_{2}}\right)$ has been assessed from $\mathrm{CO}_{2}$ adsorption isotherm for relative pressures below 0.025 (Cazorla-Amorós et al., 1998). The mesopore volume $\left(V_{\text {mes }}\right)$ was assessed as the difference between the adsorbed volume at a relative pressure of 0.98 and the $\left(V_{\mathrm{DR}}^{\mathrm{N} 2}\right)$ micropore volume. The densities of the adsorbed phases considered for the micropore volume determination were 1.023 and $0.808 \mathrm{~g} / \mathrm{mL}$ for $\mathrm{CO}_{2}$ and $\mathrm{N}_{2}$, respectively.

The surface chemistry of the activated carbon was analyzed by temperature-programed desorption (TPD). The TPD profiles were obtained in a DSC-TGA equipment (TA instruments, SDT 2960) coupled to a mass spectrometer (Thermostar, Balzers, BSC 200). Approximately, $10 \mathrm{mg}$ of sample were purged in helium flow $(100 \mathrm{~mL} / \mathrm{min} \mathrm{STP})$ for $2 \mathrm{~h}$ and then heated from room temperature up to $950^{\circ} \mathrm{C}$ at a heating rate of $10^{\circ} \mathrm{C} / \mathrm{min}$. The amounts of $\mathrm{CO}$ and $\mathrm{CO}_{2}$ desorbed were continuously monitored with the mass spectrometer.

Granular activated carbon was thoroughly washed using distilled water, filtered and dried at $110^{\circ} \mathrm{C}$ in order to clean its internal surface before its characterization and further use as As adsorbent.

\section{WATER ANALYSIS AND ARSENIC DETERMINATION}

The natural groundwater employed in this study was recovered from an aquifer in Spain, herein identified as the As-containing water. The arsenic concentration, which is the most relevant parameter for this study, was measured using inductively coupled plasma-mass spectrometry (ICP-MS) with a Perkin-Elmer 4300 DV. This technique is widely validated for As determination, being 
classified between the most sensitive ones by the World Health Organization, with a detection limit of $0.1 \mathrm{ppb}$. For the ICP-MS measurements, each sample was dissolved in $0.5 \mathrm{M} \mathrm{HNO}_{3}$, followed by filtration using a nylon membrane filter (pore diameter $\sim 350 \mathrm{~nm}$ ). The initial As concentration was $56 \mu \mathrm{g} / \mathrm{L}$ that is above the maximum contaminant level for drinking water for most countries $(10 \mu \mathrm{g} / \mathrm{L})$. The natural $\mathrm{pH}$ of the As-containing water was 8.2 at $25.0^{\circ} \mathrm{C}$. The conductivity was $595 \mu \mathrm{S} / \mathrm{cm}$ at $28.7^{\circ} \mathrm{C}$. The hardness was determined to be $80 \mathrm{mg} / \mathrm{L}$ of equivalent $\mathrm{CaCO}_{3}$. At this $\mathrm{pH}$ conditions, most of the arsenic is present as $\mathrm{HAsO}_{4}^{2-}$ (>90\%) and a small amount as $\mathrm{H}_{2} \mathrm{AsO}_{4}^{2-}(<10 \%)$, as determined using CHEAQS software, which has taken into account the As redox equilibriums and the $\mathrm{pH}$ of the As-containing groundwater (Verweij, 2014).

\section{FILTER-PRESS CELL}

The As adsorption and electroadsorption on GAC experiments have been carried out using a filter-press cell similar to that used in previous works of our research group (Berenguer et al., 2010). Figure 1 illustrates the main components of the cell. It is divided into two compartments that are herein referred as the anode and cathode, and each one being composed by (i) a flow distributor with one nozzle that can be used as water inlet or outlet, (ii) a mesh for keeping pressed the activated carbon particles and the electrode altogether, (iii) a joint that provides volume for allocating the activated carbon particles, (iv) an electrode. The compartments are tightly connected together by means of (v) two screwed iron plates, with (vi) a final joint being displayed between anode and cathode. In this work, the filter-press cell was disposed horizontally without compartment separation (i.e., no selective ionic membrane was used between the compartments). The cell has a plane electrode area of $20 \mathrm{~cm}^{2}$. The width of each electrochemical compartment is $0.9 \mathrm{~cm}$, resulting in a volume of $18 \mathrm{~cm}^{3}$. $\mathrm{An} \mathrm{Ag} / \mathrm{AgCl} 3 \mathrm{M} \mathrm{KCl}$ reference electrode was connected through a home-made lugging connector to the membrane compartment (vi), for measuring the electrode potential during the course of the experiments. In the electroadsorption experiments, a graphite electrode and platinized titanium (Pt/Ti) electrode were used as the cathode and the anode, respectively. The As-containing water was continuously stirred and pumped at $1 \mathrm{~L} / \mathrm{min}$ through the cell from a reservoir placed upwards the cell by means of centrifugal pumps. All the cell volume is filled with water, therefore providing full contact between both the electrode and the activated carbon and the electrolyte. The temperature was controlled at $25^{\circ} \mathrm{C}$ during the whole experiment using a refrigerated recirculation bath (Frigiterm-10, JP Selecta, resolution: $0.1^{\circ} \mathrm{C}$ ).

The experimental conditions, i.e., carbon dosage, adsorption time, and voltage, for a typical adsorption treatment were the following: $4 \mathrm{~g}$ of the washed GAC were placed near the cathode or near the anode for the cathodic or anodic electroadsorptions, respectively, and contacted with $400 \mathrm{~mL}$ of As-containing water. Although the contact between the GAC particles and the electrode

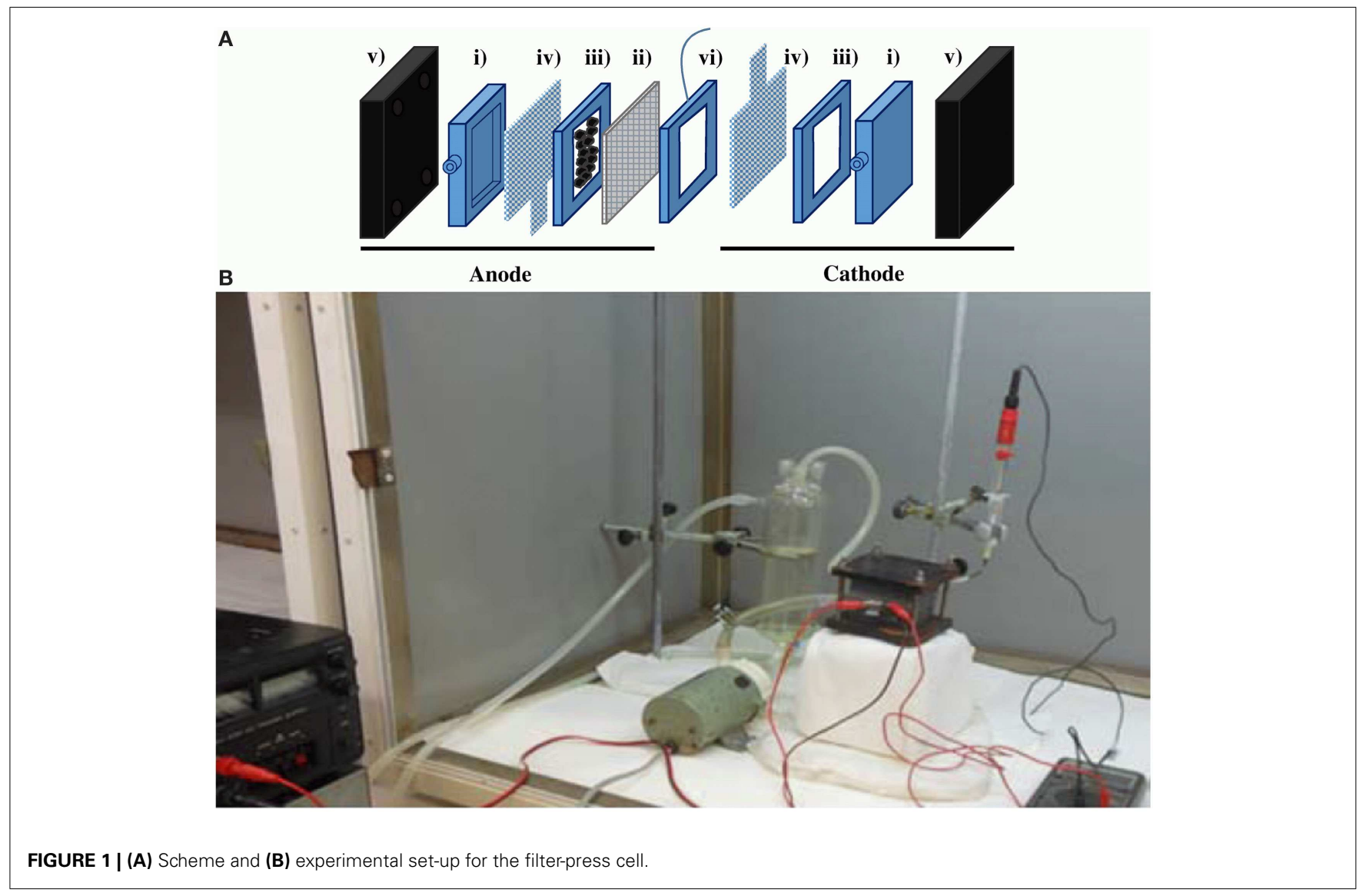



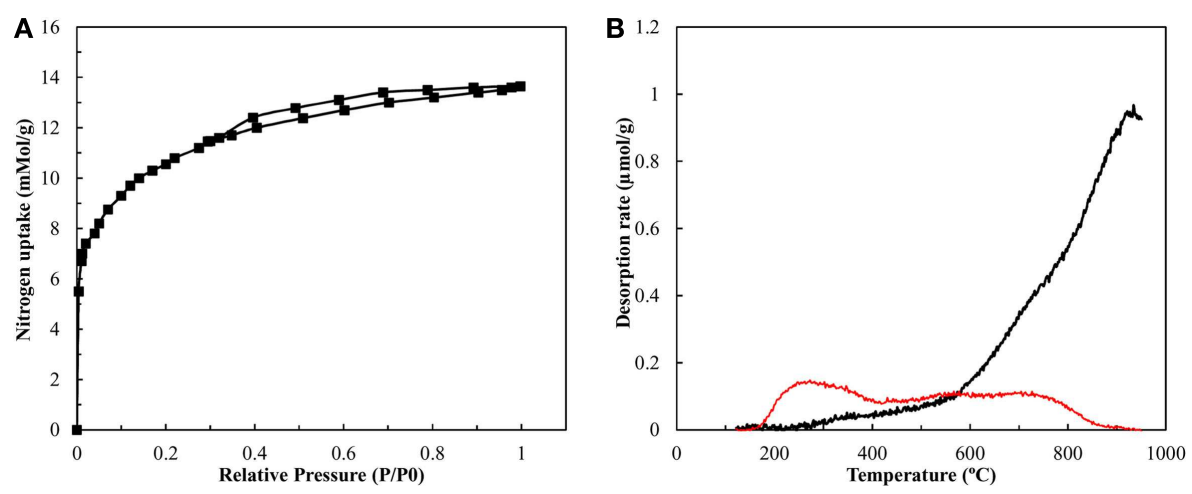

FIGURE 2 | (A) Nitrogen adsorption-desorption isotherm at $-196^{\circ} \mathrm{C}$. (B). CO (black line) and CO2 (red line) evolution rate during TPD analyses.

was slightly loose, resembling that of a fluidized bed, a series of electrochemical treatments carried out in previous works over activated carbons that were allocated inside the compartments of the cell using the same configuration have demonstrated the polarization of the surface of the carbon particles, which has been profited for achieving tunable modification of their surface chemistry (Berenguer et al., 2009). The adsorption experiments were initiated when As-containing water started circulating inside the electrochemical cell for $24 \mathrm{~h}$ in absence of current, time enough for ensuring the adsorption equilibrium. After that time, three different voltages, $1.5,2.5$, and $3.0 \mathrm{~V}$, were sequentially applied between the electrodes using an external DC Power supply (BL Ausonic FA-325, 30 V, 2.5 A). Each voltage step was imposed for $24 \mathrm{~h}$ before proceeding to the next adsorption stage. It must be highlighted that, in order to keep as simple as possible the proposed water treatment method, no supporting electrolyte was used for the electroadsorption experiments. A last desorption step in absence of current for another $24 \mathrm{~h}$ was carried out at the end of the adsorption and electroadsorption experiments in order to check the reversibility of the attained As removal during the electroadsorption experiments. Aliquots of $1 \mathrm{~mL}$ of solution were periodically sampled from the electrochemical cell and the As concentration was determined as exposed in Section "Water Analysis and Arsenic Determination.”

\section{RESULTS}

\section{CHARACTERIZATION OF THE ACTIVATED CARBON}

It is well-known that the surface characteristics of activated carbons have a strong influence in the kinetics and thermodynamics of adsorption of a given ion. A well-developed porous structure with a high degree of connectivity is necessary to minimize diffusional constraints and enhance the adsorption kinetics, while surface chemistry seems to be the primary contributor to the amount and mechanism for the adsorption of inorganic ions (Corapcioglu and Huang, 1987a,b).

The GAC utilized in this study is a commercial material used in the water treatment plants. The selection of this material and the natural water used will allow us to demonstrate the validity of this method at conditions very close to those available in a real water treatment plant. The most relevant surface properties of the
Table 1 | Surface characteristics of GAC

\begin{tabular}{lllllc}
\hline $\begin{array}{l}A_{\mathrm{BET}} \\
\left(\mathbf{m}^{2} / \mathbf{g}\right)\end{array}$ & $\begin{array}{l}\left(\boldsymbol{V}_{\mathrm{DR}}^{\mathrm{N} 2}\right) \\
\left(\mathbf{c m}^{3} / \mathbf{g}\right)\end{array}$ & $\begin{array}{l}\left(\boldsymbol{V}_{\mathrm{DR}}^{\mathrm{CO}_{2}}\right) \\
\left(\mathbf{c m}^{3} / \mathbf{g}\right)\end{array}$ & $\begin{array}{l}\mathbf{V}_{\text {meso }} \\
\left(\mathbf{c m}^{3} / \mathbf{g}\right)\end{array}$ & $\begin{array}{l}\mathrm{TPD} \text { co } \\
(\mu \mathbf{m o l} / \mathbf{g})\end{array}$ & $\begin{array}{c}\mathrm{TPD} \mathrm{CO}_{2} \\
(\mu \mathbf{m o l} / \mathbf{g})\end{array}$ \\
\hline 880 & 0.21 & 0.25 & 0.12 & 620 & 260 \\
\hline
\end{tabular}

GAC has been assessed by $\mathrm{N}_{2}$ and $\mathrm{CO}_{2}$ adsorption-desorption isotherms and TPD experiment (Figures $\mathbf{2 A , B}$, respectively). The textural properties and the amounts of surface oxygen groups that evolve as $\mathrm{CO}$ and $\mathrm{CO}_{2}$ are compiled in Table 1.

The $\mathrm{N}_{2}$ adsorption isotherm reveals that the selected GAC has a developed porous structure. The contribution of both micropores (sizes lower than $2 \mathrm{~nm}$ ) and mesopores (pore size between 2 and $50 \mathrm{~nm}$ ) is pointed out by the high $\mathrm{N}_{2}$ uptake at very low relative pressures (micropore contribution) and the slope that the isotherm presents at medium and high relative pressures (mesopore contribution). The presence of mesopores is also confirmed by the hysteresis loop of the desorption branch of the isotherm. The high porosity development of GAC is confirmed by the BET surface area and the micropore and mesopore volumes (Table 1). The $\mathrm{CO}_{2}$ adsorption isotherm complements the $\mathrm{N}_{2}$ one, since it allows to evaluate the narrow microporosity (i.e., below about $0.7 \mathrm{~nm}$ ) (Cazorla-Amorós et al., 1998). The micropore volume obtained from $\mathrm{CO}_{2}$ adsorption, compared to the $\mathrm{N}_{2}$ one, indicates that most of the microporosity has a size of about $0.5 \mathrm{~nm}$ (the micropore volumes from $\mathrm{N}_{2}$ and $\mathrm{CO}_{2}$ adsorptions are similar, Table 1) (Cazorla-Amorós et al., 1998). Thus, from the point of view of textural properties it can be concluded that the selected GAC has a well-developed pore structure that makes it a good choice for water treatment.

The surface chemistry of the activated carbon was studied by means of $\mathrm{CO}$ and $\mathrm{CO}_{2}$ TPD (Figure 2B). Each kind of surface oxygen group decomposes upon thermal treatment at different temperatures, yielding the evolution of $\mathrm{CO}$ and $\mathrm{CO}_{2}$. Thus, the nature of the surface oxygen groups can be assessed attending to the evolution temperature and the nature of evolved gases (Román-Martínez et al., 1993; Figueiredo et al., 1999). The TPD profiles of GAC revealed a high amount of oxygen surface functionalities. The $\mathrm{CO}_{2}$ evolution found at temperatures between 200 


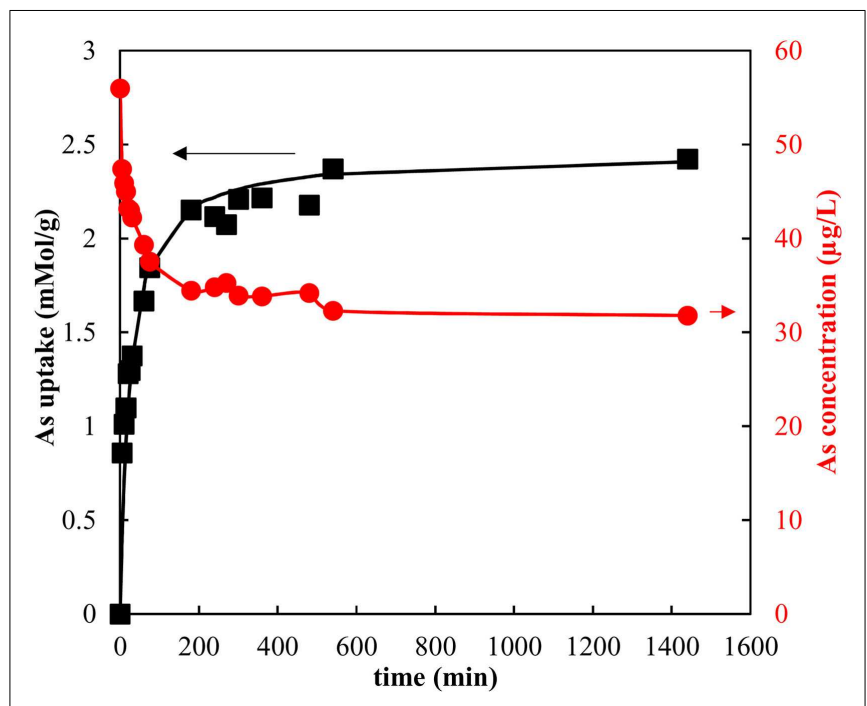

FIGURE 3 | As uptake on GAC (squares) and remaining As concentration (circles) as functions of time in absence of potential (Carbon dosage: $10 \mathrm{~g} / \mathrm{L}$, absence of potential).

and $600^{\circ} \mathrm{C}$ can be ascribed to the presence of a high amount of carboxylic and anhydride functionalities (Román-Martínez et al., 1993). The latter thermally decompose forming also a CO molecule, which is confirmed in the $\mathrm{CO}$ evolution profile. These anhydrides can be formed from the de-hydroxylation of two adjacent carboxylic groups during the drying of the samples or during the initial stages of the TPD experiment, and are expected to be hydrolyzed in aqueous media (Boehm, 2002). The presence of carbonyls and quinones, and phenols in a lower extent is derived from the observation of the CO TPD profile. The presence of surface oxygen groups constitutes a very interesting feature for the adsorption of inorganic ions, since their adsorption is strongly affected by the surface charge and by the presence of species that may act as ligand for the inorganic species to be adsorbed (Corapcioglu and Huang, 1987a; Foo and Hameed, 2009).

\section{ARSENIC ADSORPTION KINETIC ANALYSIS ON GRANULAR ACTIVATED CARBON}

Figure 3 illustrates the kinetic curve of As ion adsorption over the GAC inside the electrochemical filter-press cell. The accuracy of these results has been checked by three replications of the experiment, obtaining a high reproducibility, showing a confidence interval of $\pm 0.02 \mu \mathrm{g} / \mathrm{g}$ for a $95 \%$ confidence level. It must be noted that the As adsorption data were obtained in absence of potential. The amount of adsorbed As in the activated carbon was obtained as follows:

$$
q(t)=\frac{V \cdot\left(C_{0}-C_{t}\right)}{w_{A C}}
$$

where $C_{0}$ and $C_{\mathrm{t}}$ stands for the initial concentration and concentration obtained at a given $t$ time, $V$ represents the volume of As-containing water inside the cell, and $w_{\mathrm{AC}}$ is the carbon dosage in dry basis.
The adsorption curve shows a fast increase on As uptake up to $1 \mathrm{~h}$, followed by a slow rise toward equilibrium, which seems to be accomplished in less than $10 \mathrm{~h}$. Samples taken after 2, 3, and 4 days confirmed that equilibrium had been achieved (not shown in Figure 3 for clearness). The presence of two differentiated zones for the adsorption rate in liquid-phase adsorption is a frequently found feature of adsorption systems where activated carbons are used as adsorbent. It reflects the combination of two mass transfer resistance processes, one being related to either mass transfer through the stationary liquid boundary layer that appears over the external surface of the particle or restricted pore diffusion of the adsorbate in the wider porosity of the carbon particle, and the second, slower process, corresponding to the surface diffusion of adsorbed molecules inside the narrowest pores (Moon and Kook Lee, 1983; Yang and Al-Duri, 2005).

The total As retained by the GAC in equilibrium at the tested conditions is $2.5 \mu \mathrm{g} / \mathrm{g}$, which means that $34 \mu \mathrm{g} / \mathrm{L}$ of arsenic still remains on the solution after reaching the equilibrium. Even though this supposes a decrease on As concentration of 39\%, the As amount is still well over the $10 \mu \mathrm{g} / \mathrm{L}$ legal limit for drinkable water. Most of the works in literature concerning arsenic removal by adsorption on activated carbon report arsenic uptakes for much higher equilibrium concentrations than the one used in this work (Eguez and Cho, 1987; Rajakovic, 1992; Lorenzen et al., 1995; Pattanayak et al., 2000; Navarro and Alguacil, 2002; Chandra et al., 2010). In those few where similar As concentrations have been used, there exists a general consensus on the inability of unmodified activated carbons for reaching the As limit for a drinkable water (Gu et al., 2005; Chen et al., 2007; Bain et al., 2010), thus making necessary either a modification of the activated carbon or an electroadsorption process.

\section{ARSENIC ELECTROADSORPTION ON GRANULAR ACTIVATED CARBON}

Arsenic electroadsorption treatments at increasing voltage were sequentially conducted after As adsorption in absence of current inside the filter-press cell as shown in Section "Arsenic Adsorption Kinetic Analysis on Granular Activated Carbon.” The adsorbed arsenic as a function of time is shown in Figure $\mathbf{4}$ for a five-stage experiment. The activated carbon has been placed in the vicinity of the anode for this experiment. It can be seen that the initial arsenic adsorption stage is very similar to that reported in Figure 3. A plateau in arsenic uptake has been reached after $10 \mathrm{~h}$, with a remaining arsenic concentration of $34 \mu \mathrm{g} / \mathrm{L}$ after $24 \mathrm{~h}$ of normal adsorption. At that point, a voltage of $1.5 \mathrm{~V}$ has been imposed for $24 \mathrm{~h}$ between the electrodes, which has resulted in an additional uptake of more than $0.9 \mu \mathrm{g} / \mathrm{g}$ and an arsenic concentration of $25.3 \mu \mathrm{g} / \mathrm{L}$ in the As-containing water. Additional increases of voltage have caused an even higher As removal (As concentration in water was 21.2 and $18.2 \mu \mathrm{g} / \mathrm{L}$ after electroadsorption treatment at 2.5 and $3.0 \mathrm{~V}$ ), and in all the three cases two different adsorption regions with different kinetic rates can be differentiated, being the fastest one that occurring at the initial stage of each voltage step.

Evidences for the lack of water decomposition at the surface of the electrodes were obtained during the electroadsorption experiments. First, the occurrence of bubbles, which would have been produced if oxygen or hydrogen evolution reactions were taking place in either the anode or the cathode, was not observed in 


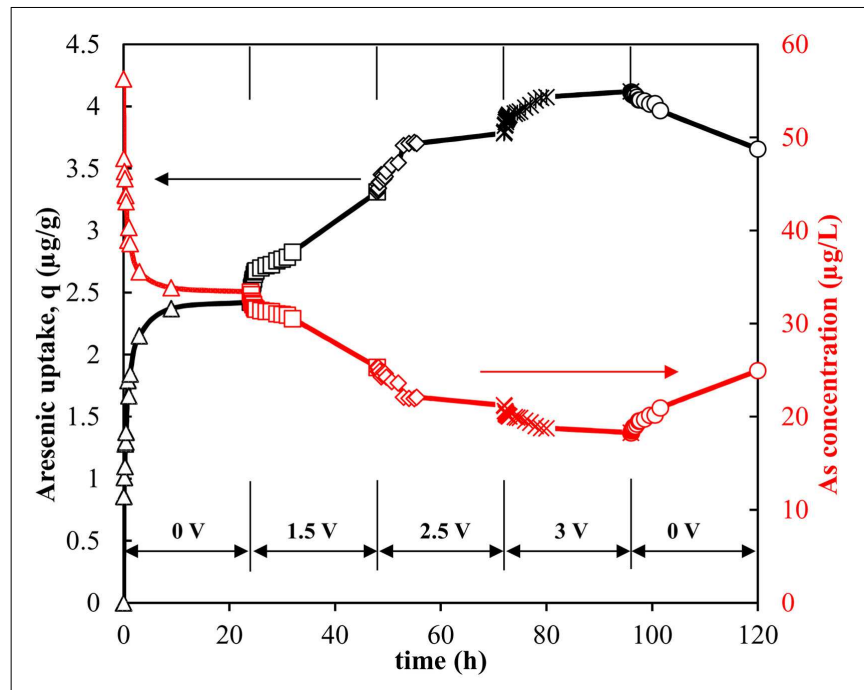

FIGURE 4 | Arsenic uptake (black line) and remaining concentration (red line) as a function of time during the adsorption and electroadsorption experiment in anodic treatment (GAC on the anode compartment). Voltage was varied sequentially during the experiment as follows: (i) normal adsorption in absence of current (triangle); (ii) electroadsorption at $1.5 \mathrm{~V}$ (square); (iii) electroadsorption at $2.5 \mathrm{~V}$ (diamond) (iv) electroadsorption at 3.0V (asterisk); (v) arsenic desorption in absence of current (circle).

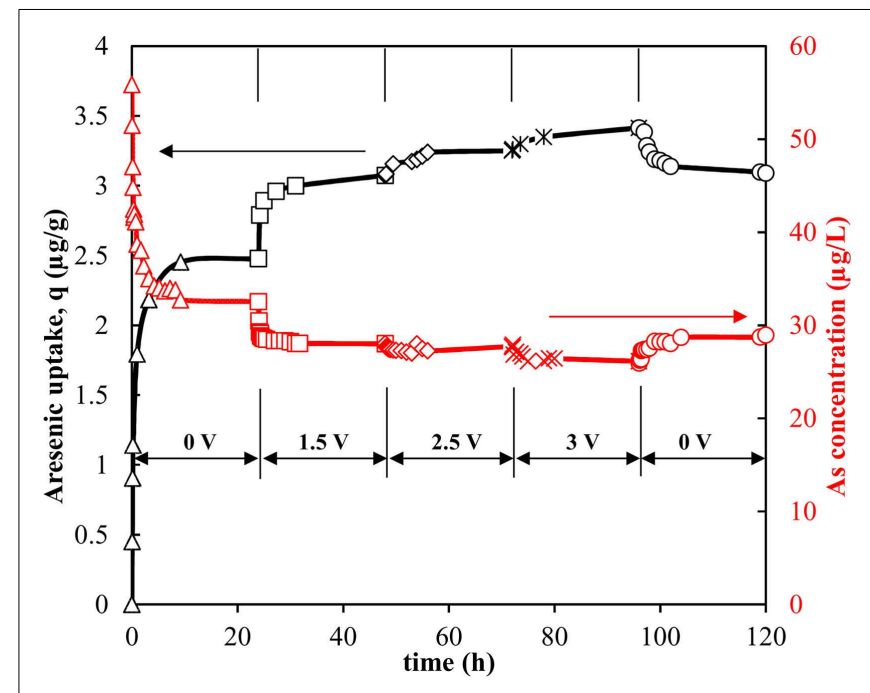

FIGURE 5 | Arsenic uptake (black line) and remaining concentration (red line) as a function of time during the adsorption and electroadsorption experiment in cathodic treatment (GAC on the cathode compartment). Voltage was varied sequentially during the experiment as follows: (i) normal adsorption in absence of current (triangle); (ii) electroadsorption at $1.5 \mathrm{~V}$ (square); (iii) electroadsorption at $2.5 \mathrm{~V}$ (diamond) (iv) electroadsorption at 3.0V (asterisk); (v) arsenic desorption in absence of current (circle) the water passing through external circuit that connects the filter press with the water reservoir. The potential of the anode was also registered using an $\mathrm{Ag} / \mathrm{AgCl}$ reference electrode and the highest anode potential during the course of the experiments was $1.05 \mathrm{~V}$ vs. $\mathrm{Ag} / \mathrm{AgCl}$ in the case of the treatment at $3 \mathrm{~V}$, being not sufficiently higher for producing a noticeable water oxidation. This is also supported by the values of intensities registered in the power supply. After the charging of the electrical double layer that is formed at the carbon surface, the intensity delivered by the power supply reached steady a state value (the required time being between $30 \mathrm{~min}$ and $1 \mathrm{~h}$ ), showing intensities as low as $0.14,0.65$, and $1.7 \mathrm{~mA}$ for the treatments at $1.5,2.5$, and $3.0 \mathrm{~V}$, respectively.

The electroadsorption experiment ended with a last step where the electrical circuit was opened in order to check the reversibility of the desorption process (Figure 4, circle dots). The desorption of As resulted in a linear increase of As concentration in water. After $24 \mathrm{~h}$, the As concentration was $25.0 \mu \mathrm{g} / \mathrm{L}$, still lower than that obtained when the As-containing water was treated with GAC using normal adsorption, while the retained As on the activated carbon was $3.7 \mu \mathrm{g} / \mathrm{g}$. This means an increase in the adsorption capacity of near $50 \%$ compared to the adsorption without applying potential.

Different conclusions can be drawn from the observation of the arsenic uptake curve for the electroadsorption experiment in cathodic configuration, Figure 5. The emplacement of GAC on the vicinities of the graphite electrode resulted in a reduced impact upon arsenic uptake during the electroadsorption experiments (red, green, and purple lines in Figure 5). Again, absence of water decomposition was observed at the employed conditions. The most relevant increase was attained in the electrotreatment conducted at $1.5 \mathrm{~V}$. In that treatment, the maximum As uptake observed was $3.1 \mu \mathrm{g} / \mathrm{g}$, which corresponds to an As concentration in water of $28.8 \mu \mathrm{g} / \mathrm{L}$. Electroadsorption treatments at 2.5 and $3.0 \mathrm{~V}$ only rendered minor increases in As uptake (The attained As concentration in water was 27.7 and $26.8 \mu \mathrm{g} / \mathrm{L}$ after $24 \mathrm{~h}$ at 2.5 and $3.0 \mathrm{~V}$, respectively). A desorption stage was conducted again after such treatments, and it was found that As concentration increased from 26.8 to $28.9 \mu \mathrm{g} / \mathrm{L}$, being this increase lower than in the case of locating the activated carbon near the anode for the electrochemical adsorption treatment.

In order to compare the effect on the uptake and the adsorption rate of the electroadsorption treatments with respect to normal adsorption treatment, the electroadsorption treatment upon cathodic and anodic polarization at $1.5 \mathrm{~V}$ was directly carried out without applying an initial adsorption step. The results for the adsorption and electroadsorption processes are compared in Figure 6. It can be seen that initially, the kinetic rate seems to follow the order normal adsorption $>$ anodic adsorption $\sim$ cathodic adsorption. After $200 \mathrm{~min}$, the order is reversed, and from that time to the end of the experiment $(24 \mathrm{~h})$, the adsorption rate is higher for the electroadsorption treatments than for the normal adsorption, being the fastest in the case of the anodic electroadsorption. After $24 \mathrm{~h}$, the As uptake has been increased in 13 and $25 \%$ in the cathodic and anodic electroadsorption treatments, respectively, compared to the normal adsorption.

Pseudo first and second order models and Linear Driving Force (LDF) model were applied to the experimental curves for the kinetic analysis of the adsorption process. Both pseudo-first and second models are widely utilized for describing the adsorption rate of ions onto activated carbons from a mathematical point of 


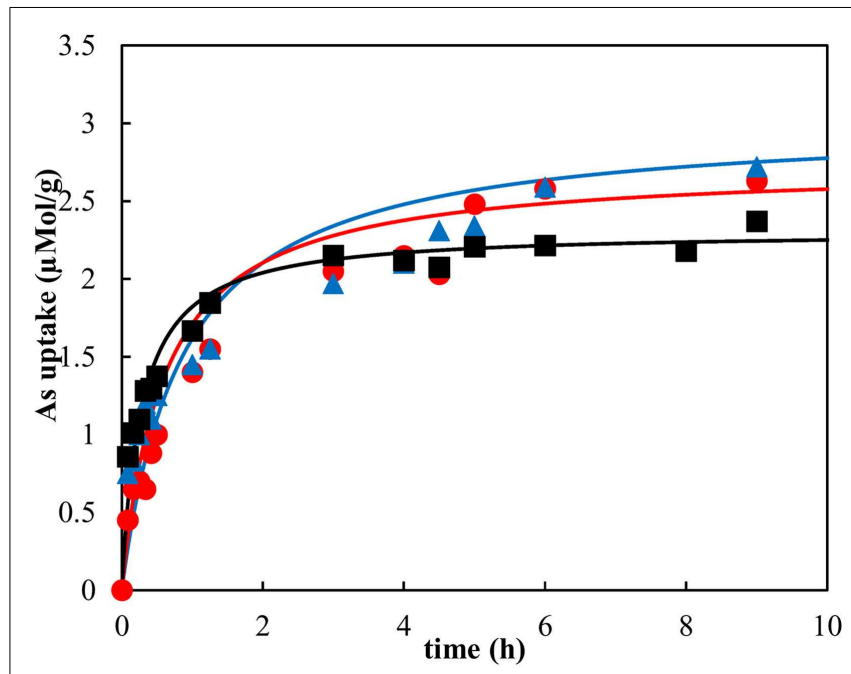

FIGURE 6 | Arsenic uptake from As-containing water in function of time obtained from normal adsorption (squares), and cathodic electroadsorption (circles) and anodic (triangles) electroadsorption (Carbon dosage: $10 \mathrm{~g} / \mathrm{L}$, absence of potential and $1.5 \mathrm{~V}$ for the normal adsorption and electroadsorption, respectively). Solid lines were obtained solving the LDF model, Eq. (4), using the optimized parameters

view, whereas LDF model have been used to estimate the diffusivity coefficient, which allows assessing the control of internal mass transfer in the particle (Otero et al., 2005). For the pseudo-first order model, the following equation was used:

$$
\ln \left[q_{\mathrm{e}}-q(t)\right]=-k_{1} \cdot t+\operatorname{Ln}\left(q_{\mathrm{e}}\right) .
$$

As for the pseudo-second order model, the related equation is expressed as follows:

$$
\frac{t}{q(t)}=\frac{1}{k_{2} q_{\mathrm{e}}^{2}}+\frac{t}{q_{\mathrm{e}}}
$$

Where $\mathrm{k}_{1}\left(\mathrm{~min}^{-1}\right)$ and $\mathrm{k}_{2}\left(\mathrm{~g} \mathrm{mg}^{-1} \mathrm{~min}^{-1}\right)$ are the kinetic rate constants for pseudo first and second order, respectively, while $q_{\mathrm{e}}$ is the As amount adsorbed by the activated carbon at the equilibrium $(\mu \mathrm{g} / \mathrm{g})$.

In the case of the LDF model, the system is considered to work as an ideal batch reactor, in absence of external mass transfer, and the following differential equation is considered for the As mass balance:

$$
\frac{\partial q}{\partial t}=k_{\mathrm{LDF}}(K \cdot C-q) .
$$

While the As concentration in the bulk of liquid can be related to the As amount adsorbed by the activated carbon:

$$
C=C_{0}-\frac{W}{V_{\mathrm{dis}}} \cdot q(t)
$$

In these equations, $W / V_{\text {dis }}$ is the carbon dosage $(\mathrm{g} / \mathrm{L})$, while $K$ is the Henry constant for As adsorption (L/g). Adsorption of As at very low concentrations, as those used in this work, can be considered linear, which allows using the Henry law for describing As uptake. Finally, $k_{\mathrm{LDF}}$ stands for the kinetic rate that can be described in function of diffusivity constant thanks to the equivalence between LDF model and homogeneous adsorption in porous carbon particles (Otero et al., 2005):

$$
k_{\mathrm{LDF}}=\frac{15 \cdot D_{\mathrm{e}}}{R_{p}^{2}}
$$

Where $D e$ is the effective diffusivity of As in the carbon particle $\left(\mathrm{m}^{2} / \mathrm{s}\right)$ and $R_{p}^{2}$ is the mean particle radius of the carbon particle (m), which was estimated to be $\sim 0.6 \mathrm{~mm}$.

Linear regression (SOLVER function of Excel @in the case of LDF) was applied for obtaining $q_{\mathrm{e}}, k_{1}, k_{2}$, or $k_{\mathrm{LDF}}$ parameters for normal adsorption and electroadsorption experiments. For all the experiments, the adsorption rate was better described by the pseudo-second order, obtaining correlation coefficients of $0.999,0.989$, and 0.996 for the normal adsorption, anodic, and cathodic electroadsorption experiments, respectively. The associated kinetic constants were obtained from the slope of the line of fit, being $0.016,0.005$, and $0.008 \mathrm{~min}^{-1}$, again for normal adsorption, anodic, and cathodic electroadsorption, respectively. LDF delivered similar accuracy in the description, and the As uptake calculated using this model has been represented for the three experiments using solid lines, Figure 6. The diffusivity coefficient for normal adsorption, cathodic, and anodic electroadsorption experiments were $5.40 \times 10^{-12}, 2.28 \times 10^{-12}$, and $1.19 \times 10^{-12} \mathrm{~m}^{2} / \mathrm{s}$, respectively. On the other hand, the Henry constant were $0.073,0.094$, and $0.115 \mathrm{~L} / \mathrm{g}$, respectively. This means that the diffusion coefficient diminishes when applying potential, whereas the uptake at equilibrium conditions and the energy of the adsorption increases. It seems that the polarization of the carbon surface and the generated electric field may decrease the diffusion coefficient because of an increase of the strength of the interaction of the ions with the pore walls.

\section{DISCUSSION}

The adsorption of arsenic ions in activated carbon surface is highly dependent on the speciation of arsenic, which in turns relies on $\mathrm{pH}$ and redox potential. $\mathrm{pH}$ of groundwater usually ranges between 5.5 and 9.0, and that of the analyzed As-containing water is 8.2. Considering the $\mathrm{pH}$ window and the thermodynamic stability of water, the Pourbaix diagram for As establishes that $\mathrm{As}(\mathrm{V})$ would be present in anionic forms $\mathrm{H}_{2} \mathrm{AsO}_{4}^{2-}$ and $\mathrm{HAsO}_{4}^{2-}$, while $\mathrm{As}$ (III) would be found in neutral state, $\mathrm{H}_{3} \mathrm{AsO}_{3}$ (Smith and Martell, 1976, 1982). However, at the $\mathrm{pH}$ conditions of this natural water $(\mathrm{pH}=8.2)$, most of the $\mathrm{As}$ is as $\mathrm{As}(\mathrm{V})$ and as $\mathrm{HAsO}_{4}^{2-}$ [as determined with CHEAQS (Verweij, 2014)]. The high amount of carboxylic functionalities, Figure 2B, will be deprotonated at the $\mathrm{pH}$ of the natural water used. In such case, the carbon surface could be negatively charged when wetted with the contaminated water, and electrostatic repulsion of the $\mathrm{As}(\mathrm{V})$ anions could partially explain the low As uptake when working in normal adsorption, Figure 3.

A notorious enhancement on As removal is attained when using an electroadsorption treatment in anodic configuration, Figure 4. 
There may be different processes contributing in such a good result, however, the straightforward interpretation is that activated carbon in direct contact with the $\mathrm{Pt} / \mathrm{Ti}$ electrode will be positively charged upon anodic polarization. In such a case, the concentration of anions over the carbon surface will increase due to the favorable electrostatic interactions between the ions and the surface. Taking into account that most of the As is in anionic form, this mechanism will be favored.

Furthermore, the oxidizing agents formed upon anodic polarization of the $\mathrm{Ti} / \mathrm{Pt}$ electrode can also oxidize the surface of the activated carbon, increasing the population of surface oxygen groups (Berenguer et al., 2009). This can be helpful for the elimination of the other interfering cations also found in As-containing water. It has been reported that cation adsorption on oxidized activated carbon samples can be described either by ion-exchange mechanism or by formation of hydroxyl complexes with the participation of hydroxyl groups from the surface of the activated carbon (Corapcioglu and Huang, 1987a; Swiatkowski et al., 2004). On cathodic polarization, most of the aforementioned effects are negligible, thus rendering a lower adsorption enhancement than in the case of anodic electroadsorption, Figure 5. It is important to note that electroadsorption has a reduced or even a negative impact on the rate of the adsorption process (see the values for the kinetic constants obtained by the pseudo-second order and LDF models), which is still diffusion-controlled, as can be observed in the long adsorption times and slow As uptakes for the electroadsorption experiments in Figure 6.

Another interesting result is the reversibility of electroadsorption observed on the last step of the experiments illustrated in Figures 4 and 5. This outcome points out that electrostatic interaction does occur between the polarized carbon surface and As species, and those species slowly diffuse out of the pore network after stopping the applied voltage between the electrodes. This effect is more intense on the anodic polarization because part of the carbon particles can be positively charged, therefore increasing the interaction with the As anions from the solution.

In conclusion, the electroadsorption enhances arsenic uptake by activated carbons. This positive outcome of the treatment has been obtained for the first time using a natural groundwater polluted with low As amount in the ppb range, demonstrating that the treatment can operate under real conditions. The proposed treatment is viable using readily available materials and devices, i.e., employing a common activated carbon for water treatment and filter-press cell. The best results are obtained using anodic polarization, where the positive charge induced on the carbon surface favors the adsorption of the As(V) anions present in the studied natural water.

\section{ACKNOWLEDGMENTS}

The authors gratefully thank the economic support from the Ministerio de Economía y Competitividad and FEDER (Projects MAT2013-42007-P and CTQ2012/31762) and Generalitat Valenciana (PROMETEO/2013/038 and PROMETEOII/2014/010). Ramiro Ruiz-Rosas also thanks MINECO for support through a "Juan de la Cierva" contract (JCI-2012-12664).

\section{REFERENCES}

An, B., Steinwinder, T. R., and Zhao, D. (2005). Selective removal of arsenate from drinking water using a polymeric ligand exchanger. Water Res. 39, 4993-5004. doi:10.1016/j.watres.2005.10.014

Babel, S., and Kurniawan, T. A. (2003). Low-cost adsorbents for heavy metals uptake from contaminated water: a review. J. Hazard. Mater. 97, 219-243. doi:10.1016/S0304-3894(02)00263-7

Babić, B. M., Milonjić, S. K., Polovina, M. J., Čupić, S., and Kaludjerovic, B. V. (2002). Adsorption of zinc, cadmium and mercury ions from aqueous solutions on an activated carbon cloth. Carbon N. Y. 40, 1109-1115. doi:10.1016/S0008-6223(01) 00256- 1

Bailey, S. E., Olin, T. J., Bricka, R. M., and Adrian, D. D. (1999). A review of potentially low-cost sorbents for heavy metals. Water Res. 33, 2469-2479. doi:10.1016/S0043-1354(98)00475-8

Bain, E. J., Calo, J. M., Spitz-Steinberg, R., Kirchner, J., and Axén, J. (2010). Electrosorption/electrodesorption of arsenic on a granular activated carbon in the

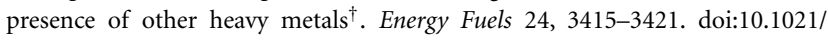
ef $901542 \mathrm{q}$

Ban, A., Schafer, A., and Wendt, H. (1998). Fundamentals of electrosorption on activated carbon for wastewater treatment of industrial effluents. J. Appl. Electrochem. 28, 227-236. doi:10.1023/A:1003247229049

Berenguer, R., Marco-Lozar, J. P., Quijada, C., Cazorla-Amorós, D., and Morallón, E. (2009). Effect of electrochemical treatments on the surface chemistry of activated carbon. Carbon N. Y. 47, 1018-1027. doi:10.1016/j.carbon.2008.12.022

Berenguer, R., Marco-Lozar, J. P., Quijada, C., Cazorla-Amorós, D., and Morallón, E. (2010). Electrochemical regeneration and porosity recovery of phenol-saturated granular activated carbon in an alkaline medium. Carbon N. Y. 48, 2734-2745. doi:10.1016/j.carbon.2010.03.071

Boehm, H. P. (2002). Surface oxides on carbon and their analysis: a critical assessment. Carbon N. Y. 40, 145-149. doi:10.1016/S0008-6223(01)00165-8

Borho, M., and Wilderer, P. (1996). Optimized removal of arsenate(III) by adaptation of oxidation and precipitation processes to the filtration step. Water Sci. Technol. 34, 25-31. doi:10.1016/S0273-1223(96)00783-4

Cazorla-Amorós, D., Alcañiz-Monge, J., de la casa-Lillo, M. A., and Linares-Solano, A. (1998). $\mathrm{CO}_{2}$ as an adsorptive to characterize carbon molecular sieves and activated carbons. Langmuir 14, 4589-4596. doi:10.1021/la980198p

Chandra, V., Park, J., Chun, Y., Lee, J. W., Hwang, I.-C., and Kim, K. S. (2010). Waterdispersible magnetite-reduced graphene oxide composites for arsenic removal. ACS Nano 4, 3979-3986. doi:10.1021/nn1008897

Chen, B., Zhu, Z., Ma, J., Qiu, Y., and Chen, J. (2013). Surfactant assisted Ce-Fe mixed oxide decorated multiwalled carbon nanotubes and their arsenic adsorption performance. J. Mater. Chem. A 1, 11355-11367. doi:10.1039/C3TA11827D

Chen, W., Parette, R., Zou, J., Cannon, F. S., and Dempsey, B. A. (2007). Arsenic removal by iron-modified activated carbon. Water Res. 41, 1851-1858. doi:10. 1016/j.watres.2007.01.052

Corapcioglu, M. O., and Huang, C. P. (1987a). The adsorption of heavy metals onto hydrous activated carbon. Water Res. 21, 1031-1044. doi:10.1016/0043-1354(87) 90024-8

Corapcioglu, M. O., and Huang, C. P. (1987b). The surface acidity and characterization of some commercial activated carbons. Carbon N. Y. 25, 569-578. doi:10.1016/0008-6223(87)90200-4

Derbyshire, F., Jagtoyen, M., Andrews, R., Rao, A., Martín-Gullón, I., and Grulke, E. (2001). "Carbon materials in environmental applications," in Chemistry and Physics of Carbon, ed. L. R. Radovic (New York: Marcel Dekker, Inc), 1-66.

Eguez, H. E., and Cho, E. H. (1987). Adsorption of arsenic on activated charcoal. J. Metals 39, 38-41. doi:10.1007/BF03258040

Figueiredo, J., Pereira, M. F., Freitas, M. M., and Órfão, J. J. (1999). Modification of the surface chemistry of activated carbons. Carbon N. Y. 37, 1379-1389. doi:10.1016/S0008-6223(98)00333-9

Foo, K. Y., and Hameed, B. H. (2009). A short review of activated carbon assisted electrosorption process: An overview, current stage and future prospects. J. Hazard. Mater. 170, 552-559. doi:10.1016/j.jhazmat.2009.05.057

Gabelich, C. J., Tran, T. D., and Suffet, I. H. (2002). Electrosorption of inorganic salts from aqueous solution using carbon aerogels. Environ. Sci. Technol. 36, 3010-3019. doi:10.1021/es0112745

Ghosh, A., and Lee, Y. H. (2012). Carbon-based electrochemical capacitors. ChemSusChem 5, 480-499. doi:10.1002/cssc.201100645 
Giles, D. E., Mohapatra, M., Issa, T. B., Anand, S., and Singh, P. (2011). Iron and aluminium based adsorption strategies for removing arsenic from water. J. Environ. Manage. 92, 3011-3022. doi:10.1016/j.jenvman.2011.07.018

Gomes, J. A. G., Daida, P., Kesmez, M., Weir, M., Moreno, H., Parga, J. R., et al. (2007). Arsenic removal by electrocoagulation using combined Al-Fe electrode system and characterization of products. J. Hazard. Mater. 139, 220-231. doi:10.1016/j.jhazmat.2005.11.108

Gu, Z., Fang, J., and Deng, B. (2005). Preparation and evaluation of GAC-based ironcontaining adsorbents for arsenic removal. Environ. Sci. Technol. 39, 3833-3843. doi:10.1021/es048179r

Kobya, M., Demirbas, E., Senturk, E., and Ince, M. (2005). Adsorption of heavy metal ions from aqueous solutions by activated carbon prepared from apricot stone. Bioresour. Technol. 96, 1518-1521. doi:10.1016/j.biortech.2004.12.005

Lee, Y., Um, I., and Yoon, J. (2003). Arsenic(III) oxidation by iron(VI) (ferrate) and subsequent removal of arsenic(V) by iron(III) coagulation. Environ. Sci. Technol. 37, 5750-5756. doi:10.1021/es034203

Lorenzen, L., van Deventer, J. S. J., and Landi, W. M. (1995). Factors affecting the mechanism of the adsorption of arsenic species on activated carbon. Miner. Eng. 8, 557-569. doi:10.1016/0892-6875(95)00017-K

Mohan, D., and Pittman, C. U. Jr. (2007). Arsenic removal from water/wastewater using adsorbents - a critical review. J. Hazard. Mater. 142, 1-53. doi:10.1016/j. jhazmat.2007.01.006

Moon, H., and Kook Lee, W. (1983). Intraparticle diffusion in liquid-phase adsorption of phenols with activated carbon in finite batch adsorber. J. Colloid Interface Sci. 96, 162-171. doi:10.1016/0021-9797(83)90018-8

Morallón, E., Arias-Pardilla, J., Calo, J. M., and Cazorla-Amorós, D. (2009). Arsenic species interactions with a porous carbon electrode as determined with an electrochemical quartz crystal microbalance. Electrochim. Acta 54, 3996-4004. doi:10.1016/j.electacta.2009.02.023

Nasser, H., and Kheir-Bek, R. (2014). Determination of arsenic (As) in some environmental samples utilizing potentiometric titration: under modified analytical and technical conditions. Pharma Res. 11, 17-26.

Navarro, P., and Alguacil, F. J. (2002). Adsorption of antimony and arsenic from a copper electrorefining solution onto activated carbon. Hydrometallurgy 66, 101-105. doi:10.1016/S0304-386X(02)00108-1

Noked, M., Avraham, E., Soffer, A., and Aurbach, D. (2009). The rate-determining step of electroadsorption processes into nanoporous carbon electrodes related to water desalination. J. Phys. Chem. C 113, 21319-21327. doi:10.1021/ jp905987j

Otero, M., Zabkova, M., and Rodrigues, A. E. (2005). Adsorptive purification of phenol wastewaters: Experimental basis and operation of a parametric pumping unit. Chem. Eng. J. 110, 101-111. doi:10.1016/j.cej.2005.02.033

Pattanayak, J., Mondal, K., Mathew, S., and Lalvani, S. B. (2000). A parametric evaluation of the removal of As(V) and As(III) by carbon-based adsorbents. Carbon N. Y. 38, 589-596. doi:10.1016/S0008-6223(99)00144-X

Radovic, L. R., Moreno-Castilla, C., and Rivero-Utrilla, J. (2001). "Carbon materials as adsorbents in aqueous solutions," in Chemistry and Physics of Carbon, ed. L. R. Radovic (New York: Marcel Dekker, Inc), 227-405.
Rajakovic, L. V. (1992). The sorption of arsenic onto activated carbon impregnated with metallic silver and copper. Sep. Sci. Technol. 27, 1423-1433. doi:10.1080/ 01496399208019434

Román-Martínez, M. C., Cazorla-Amorós, D., Linares-Solano, A., and de Lecea, C. S.-M. (1993). Tpd and TPR characterization of carbonaceous supports and Pt/C catalysts. Carbon N. Y. 31, 895-902. doi:10.1016/0008-6223(93)90190-L

Smith, R. M., and Martell, A. E. (1976). Critical Stability Constants, Vol. 3. New York: Plenum Press.

Smith, R. M., and Martell, A. E. (1982). Critical Stability Constants, Vol. 6. New York: Plenum Press.

Sun, Z., Yu, Y., Pang, S., and Du, D. (2013). Manganese-modified activated carbon fiber (Mn-ACF): Novel efficient adsorbent for Arsenic. Appl. Surf. Sci. 284, 100-106. doi:10.1016/j.apsusc.2013.07.031

Swiatkowski, A., Pakula, M., Biniak, S., and Walczyk, M. (2004). Influence of the surface chemistry of modified activated carbon on its electrochemical behaviour in the presence of lead(II) ions. Carbon N. Y. 42, 3057-3069. doi:10.1016/j.carbon.2004.06.043

Tyson, J. (2013). The determination of arsenic compounds: a critical review. ISRN Anal. Chem. 2013, e835371. doi:10.1155/2013/835371

Verweij, W. (2014). CHemical Equilibria in AQuatic Systems (CHEAQS) Next program. Available at: http://www.cheaqs.eu/index.html

Yang, X., and Al-Duri, B. (2005). Kinetic modeling of liquid-phase adsorption of reactive dyes on activated carbon. J. Colloid Interface Sci. 287, 25-34. doi:10.1016/j.jcis.2005.01.093

Zhang, K., Dwivedi, V., Chi, C., and Wu, J. (2010a). Graphene oxide/ferric hydroxide composites for efficient arsenate removal from drinking water. J. Hazard. Mater. 182, 162-168. doi:10.1016/j.jhazmat.2010.06.010

Zhang, S., Li, X., and Chen, J. P. (2010b). Preparation and evaluation of a magnetitedoped activated carbon fiber for enhanced arsenic removal. Carbon N. Y. 48, 60-67. doi:10.1016/j.carbon.2009.08.030

Conflict of Interest Statement: The authors declare that the research was conducted in the absence of any commercial or financial relationships that could be construed as a potential conflict of interest.

Received: 04 September 2014; accepted: 06 November 2014; published online: 24 November 2014.

Citation: Beralus J-M, Ruiz-Rosas R, Cazorla-Amorós D and Morallón E (2014) Electroadsorption of arsenic from natural water in granular activated carbon. Front. Mater. 1:28. doi: 10.3389/fmats.2014.00028

This article was submitted to Carbon-Based Materials, a section of the journal Frontiers in Materials.

Copyright (C) 2014 Beralus, Ruiz-Rosas, Cazorla-Amorós and Morallón. This is an open-access article distributed under the terms of the Creative Commons Attribution License (CC BY). The use, distribution or reproduction in other forums is permitted, provided the original author(s) or licensor are credited and that the original publication in this journal is cited, in accordance with accepted academic practice. No use, distribution or reproduction is permitted which does not comply with these terms. 